\title{
Regionalisasi Wakaf Tanah di Provinsi Aceh: Suatu Telaah Pemetaan dan Kebijakan
}

\section{Regionalization of Waqf Land in Aceh Province: A Mapping and Policy Study}

\author{
Hafiizh Maulana ${ }^{1}$, Nurul Iski ${ }^{2}$, Aditya Putra Pratama ${ }^{3}$ \\ FEBI UIN Ar-Raniry, Darussalam, Banda Aceh, Indonesia 23111 \\ email: ${ }^{1}$ hafiizh.maulana@ar-raniry.ac.id, ${ }^{2}$ nurul.iski@gmail.com, \\ 3 pratamatya24@gmail.com
}

\begin{abstract}
This research was conduct to identify the regionalization of land waqf in Aceh Province based on compilation of waqf data sourced from Sistem Informasi Wakaf (Siwak) The Ministry of Religious Affairs of the Republic of Indonesia. This research is interesting because there are no studies that have conducted mapping land of waqf. Mapping of potential land waqf in Aceh Province wants to offer an easy solution in terms of inventory potential region as making policy. The methode used by descriptive analysis which is also elaborated with Geographic Information System analysis (GIS) tool. Based on the results of the GIS mapping conducted in the area of land waqf in Aceh Province, land waqf is concentrated in North Aceh District covering $63 \%$ of the distribution waqf land in Aceh. However, land Waqf has not been synergy optimally managed with the process of certifying legality. Regionalization needs two types of policy schemes; those are nazhir and waqif perspectives. Nazhir perspective policy is carried out in the scheme of forming professional waqf nazhir institutions. Meanwhile, the waqf perspective policy needs to be carried out with spatial planning and waqf area with the establishment of an Aceh waqf management body regulated in a Perda/Qanun.
\end{abstract}

Keywords: Mapping, land waqf, policy, nazhir, waqif

\begin{abstract}
Abstrak. Penelitian ini lahir dalam upaya mengidentifikasi secara utuh regionalisasi wakaf tanah di Provinsi Aceh berdasarkan hasil kompilasi data wakaf yang bersumber dari Sistem Informasi Wakaf (Siwak) Kementerian Agama Republik Indonesia. Regionalisasi yang didukung dengan tampilan peta administratif Provinsi Aceh menarik untuk ditelaah karena belum adanya pemetaan yang dilakukan oleh Pemerintah Pusat dan daerah. Maka, penelitian ini memiliki urgensi yang penting berkaitan dengan solusi kemudahan pendataan wakaf tanah sebagai basis data dalam kebijakan perwakafan di Provinsi Aceh. Metode analisis dilakukan secara deskriptif yang juga dielaborasikan dengan hasil pemetaan wakaf tanah Provinsi Aceh melalui alat analisis Geographic Information Sysyem (GIS). Berdasarkan hasil pemetaan GIS yang dilakukan pada luasan wakaf tanah di seluruh kabupaten/kota Provinsi Aceh, wakaf tanah terkonsentrasi di Kab. Aceh Utara seluas 63\% dari total lahan wakaf di Aceh. Namun demikian, wakaf tanah belum optimal dikelola secara sinergis dengan proses pengurusan legalitas bersertifikasi. Regionalisasi menghasilkan dua bentuk skema kebijakan yang perlu dilakukan berdasarkan perspektif nazir dan wakif. Kebijakan perspektif nazir dilakukan dalam skema pembentukan kelembagaan nazir wakaf yang profesional untuk pemanfataan ekonomis nilai tanah wakaf. Sementara, kebijakan perspektif wakif perlu dilakukan dengan perencanaan tata ruang dan wilayah wakaf dengan pembentukan badan pengelola wakaf Aceh yang diatur dalam Perda/Qanun.
\end{abstract}

Kata kunci: Pemetaan, wakaf tanah, kebijakan, nazir, wakif

\section{PENDAHULUAN}

Pembangunan yang dilaksanakan oleh Pemerintah pada dasarnya bertujuan untuk menaikkan perekonomian masyarakat, sehingga pada akhirnya dapat meningkatkan kesejahteraan masyarakat yang lebih baik dan merata. Aspek pemerataan ini sering terabaikan dengan semangat pembangunan yan terpusat pada sektor tertentu sehingga timbul istilah egosentris dalam pembangunan. Dominasi distribusi aset dan lahan pada kelompok sektor ekonomi tertentu sering mengakibatkan munculnya kesenjangan pembangunan. Dalam perspektif Islam, pembangunan perekonomian sejatinya adalah meningkatkan aspek kesejahteraan melalui pemerataan. Almizan (2016) menyatakan bahwa 
pembangunan ekonomi dalam Islam merupakan aktivitas multidimensional sehingga semua usaha harus diserahkan pada keseimbangan berbagai faktor dan tidak menimbulkan ketimpangan.

Salah satu instrumen dalam keadilan distributif penyaluran kekayaan harta/aset dilakukan melalui mekanisme wakaf. Wakaf merupakan pranata keagamaan dalam Islam yang memiliki hubungan langsung secara fungsional dengan upaya pemecahan masalah-masalah sosial dan kemanusiaan, seperti pengentasan kemiskinan dan pemberdayaan ekonomi umat. Wakaf merupakan ibadah yang bercorak sosial ekonomi yang cukup penting. Menurut sejarah Islam klasik, wakaf telah memainkan peran yang sangat signifikan dalam meningkatkan kesejahteraan kaum Muslimin, baik di bidang pendidikan, pelayanan kesehatan, pelayanan sosial dan kepentingan publik, kegiatan keagamaan, pengembangan ilmu pengetahuan, serta peradaban Islam secara umum.

Wakaf secara etimologi berasal dari kata al-waqf yang sering disamakan dengan at-tahbis atau attasbil yang bermakna al-habs 'an taşarruf, yakni mencegah dari mengelola (Az-Zuhaili, 2011). Wakaf merupakan salah satu bagian dari aktivitas muamalah dalam rangka redistribusi harta/aset untuk kemaslahatan umat. Wakaf berperan dalam meningkatkan kesejahteraan masyarakat, di mana kekayaan seseorang dapat dirasakan kemanfaatannya dalam ruang dan jangka waktu yang panjang. Universitas al-Azhar dengan kemampuannya memberikan beasiswa kepada semua mahasiswanya merupakan contoh kontribusi wakaf bagi pemberdayaan masyarakat di bidang pendidikan (Anas dan Ryandono, 2017).

Secara regulasi, sejarah perwakafan di Indonesia menemukan momentum pada tahun 2004. Regulasi wakaf mulai diperkuat dengan lahirnya UU No. 41 Tahun 2004 tentang Wakaf, yang mengatur tujuan dan objek wakaf secara lebih kompherensif. Kemudian tata kelola wakaf diperkuat dengan lahirnya Peraturan Pemerintah No. 42 Tahun 2006 yang mengamanatkan berdirinya Badan Wakaf Indonesia (BWI). Maka, tahun 2007 berdirilah Badan Wakaf Indonesia yang mempunyai wewenang penuh dalam mengatur dan mengembangkan perwakafan di Indonesia berdasarkan Keputusan Presiden (Kepres) No. 75/M tahun 2007 (BWI, 2010).

Distribusi harta/kekayaan melalui mekanisme wakaf masih belum berkembang dengan baik. Prihatini (2005) memaparkan bahwa wakaf merupakan suatu instrumen ekonomi Islam yang belum diberdayakan secara optimal di Indonesia. Sedangkan di negara lain seperti Mesir, Saudi Arabia, Yordania, Turki, Bangladesh, Mesir, Malaysia dan Amerika Serikat, wakaf telah dikembangkan sebagai salah satu lembaga sosial ekonomi Islam yang dapat membantu berbagai kegiatan umat dan mengatasi masalah umat seperti kemiskinan.

Berdasarkan data dari Siwak Kemenag RI (2018), hingga saat ini terdapat 375,205 jumlah lokasi tanah yang telah diwakafkan dengan luasan tanah wakaf mencapai 50,403.36 Ha. Dari jumlah lokasi tersebut, sebanyak $61.68 \%$ sudah tersertifikasi. Wakaf tanah Provinsi Aceh terdistribusi secara optimal pada tahun 2010, dimana terjadi lonjakan luasan tanah yang diwakafkan. Selengkapnya data perbandingan wakaf tanah Provinsi Aceh dan Indonesia ditampilkan dalam tabel berikut ini. 
Tabel 1 Perbandingan lokasi dan luas tanah wakaf antara Provinsi Aceh dengan Indonesia

\begin{tabular}{|c|c|c|c|c|c|}
\hline \multirow{2}{*}{ Tahun } & \multirow{2}{*}{ Daerah } & \multicolumn{2}{|c|}{ Lokasi Wakaf (lokasi) } & \multicolumn{2}{|c|}{ Luasan Tanah Wakaf (ha) } \\
\hline & & Jumlah & Persentase & Luas [Ha] & Persentase \\
\hline \multirow[t]{2}{*}{2009} & Aceh & 24,086 & \multirow{2}{*}{$5.34 \%$} & $74,020.51$ & \multirow{2}{*}{$27.21 \%$} \\
\hline & Indonesia & 451,305 & & $271,985.48$ & \\
\hline \multirow[t]{2}{*}{2010} & Aceh & 27,416 & \multirow{2}{*}{$6.57 \%$} & $133,323.36$ & \multirow{2}{*}{$41.90 \%$} \\
\hline & Indonesia & 417,265 & & $318,158.69$ & \\
\hline \multirow[t]{2}{*}{2011} & Aceh & 27,416 & \multirow{2}{*}{$6.51 \%$} & $133,323.36$ & \multirow{2}{*}{$13.74 \%$} \\
\hline & Indonesia & 420,879 & & $970,200.06$ & \\
\hline \multirow[t]{2}{*}{2012} & Aceh & 24,864 & \multirow{2}{*}{$5.91 \%$} & $76,782.59$ & \multirow{2}{*}{$5.45 \%$} \\
\hline & Indonesia & 420,754 & & $1,407,713.93$ & \\
\hline \multirow[t]{2}{*}{2013} & Aceh & 24,898 & \multirow{2}{*}{$5.72 \%$} & $76,786.90$ & \multirow{2}{*}{$18.54 \%$} \\
\hline & Indonesia & 435,395 & & $414,246.43$ & \\
\hline \multirow[t]{2}{*}{2014} & Aceh & 24,898 & \multirow{2}{*}{$5.72 \%$} & $76,786.90$ & \multirow{2}{*}{$18.54 \%$} \\
\hline & Indonesia & 435,395 & & $414,246.43$ & \\
\hline \multirow[t]{2}{*}{2015} & Aceh & 24,898 & \multirow{2}{*}{$5.71 \%$} & $76,786.90$ & \multirow{2}{*}{$18.54 \%$} \\
\hline & Indonesia & 435,768 & & $414,246.43$ & \\
\hline \multirow[t]{2}{*}{2016} & Aceh & 23,392 & \multirow{2}{*}{$5.37 \%$} & $76,786.90$ & \multirow{2}{*}{$17.66 \%$} \\
\hline & Indonesia & 435,768 & & $434,702.32$ & \\
\hline \multirow[t]{2}{*}{2017} & Aceh & 13,178 & \multirow{2}{*}{$3.6 \%$} & $7,211.23$ & \multirow{2}{*}{$14.56 \%$} \\
\hline & Indonesia & 366,713 & & $49,590.56$ & \\
\hline
\end{tabular}

Sumber: Kemenag, 2009-2017

Praktik perwakafan Provinsi Aceh berdasarkan tabel di atas menunjukkan bahwa pada 2017 tercatat jumlah lokasi tanah wakaf sebanyak 13,178 lokasi dengan luas 7,211.23 Ha. Sementara itu, secara nasional, jumlah tanah wakaf terdata sebanyak 366,713 lokasi dengan luasan tanah 49,590.56 Ha. Provinsi Aceh menjadi daerah dengan luasan tanah wakaf nomor dua tertinggi setelah Sumatera Utara yang memiliki luas tanah wakaf sebesar 8,223.16 Ha. Berdasarkan data tabulasi wakaf tanah selama tahun 2009-2017, rata-rata persentase lokasi jumlah wakaf tanah Aceh sebesar 5.61\%. Sementara itu, rata-rata luas tanah wakaf di Provinsi Aceh sebesar 19.57\%. Wakaf tanah mengalami kenaikan yang signifikan pada rahun 2010 yang diperkirakan terjadi karena adanya kemudahan pengurusan sertifikat wakaf tanah di Badan Pertanahan Nasional.

Secara kelembagaan, Provinsi Aceh sudah mengukuhkan Badan Wakaf Indonesia (BWI) perwakilan Aceh pada tahun 2015, yang secara struktural berada dibawah Kanwil Kementerian Agama Provinsi Aceh. Optimalisasi kinerja wakaf tanah Aceh perlu mendapatkan perhatian yang besar karena adanya nilai kemanfaatan yang besar dalam penggunaan harta dan aset wakaf. Berdasakan data statistik wakaf tanah Indonesia pada tahun 2015, luasan tanah wakaf Aceh menjadi yang terluas di Indonesia. Namun, dari jumlah tersebut Aceh baru mencapai proses sertifikasi sebesar 45\% yang masih berada di bawah Jawa Barat, Kalimantan Barat, dan Nusa Tenggara Barat (Huda, 2015). Muncul kekhawatiran pengelolaan wakaf oleh BWI masih tumpang tindih karena secara kelembagaan tugas wakaf berada dalam lintas koordinasi Kanwil Kemenag Aceh.

Provinsi Aceh pernah dihebohkan dengan pemberitaan Baitul Asyi, hasil wakaf tanah abadi oleh ulama Habib Bugak di Makkah, Arab Saudi. Abubakar (2018) menyatakan bahwa berdasarkan akta yang tertulis, Habib Bugak mewakafkan sepetak tanah dengan sebuah rumah bertingkat di atasnya yang terletak di daerah Qararah, Syamiah, Mekkah. Rumah ini beliau wakafkan sebagai tempat tinggal jamaah haji asal Aceh dan tempat tinggal bagi orang Aceh yang menetap di Mekkah. Kalau dua kelompok ini karena sesuatu sebab tidak ada lagi di Mekkah, maka rumah tersebut digunakan untuk membiayai mahasiswa Asia Tenggara yang belajar di Mekkah. Pada akhirnya, bila semuanya 
sudah tidak ada, maka tanah dan rumah wakaf tersebut digunakan untuk kemaslahatan Masjidil Haram. Keadaan ini menimbulkan persepsi pentingnya wakaf tanah di masa mendatang untuk peningkatan nilai guna atas lahan.

Harta wakaf tanah tanah yang terus berkembang dan memberikan nilai manfaat ini mendapat respons yang besar dari Pemerintah Aceh akan pentingnya nilai ibadah wakaf yang mampu dirasakan sampai generasi nazir wakaf yang kelima, Munir bin Abdul Ghani Asyi. Distribusi kekayaan/harta melalui mekanisme ibadah wakaf disadari kemanfaatannya dalam output pembangunan dengan adanya perluasan investasi ekonomi.

Penelitian ini lahir dalam upaya mengidentifikasi data wakaf tanah Provinsi Aceh berdasarkan data wakaf tanah pada Sistem Informasi Wakaf Tanah (Siwak) Kemenag RI. Terdapat dua isu utama yang ingin dijawab dalam penelitian regionalisasi wakaf tanah, yaitu potensi wakaf tanah melalui pemetaan hasil kompilasi data wakaf tanah kabupaten/kota Provinsi Aceh, dan hasil dari tampilan pemetaan dan tabulasi data untuk dilanjutkan dengan desain kebijakan wakaf tanah di Provinsi Aceh. Penelitian ini secara spesifik bertujuan untuk menawarkan perencanaan wakaf tanah melalui identifikasi lahan wakaf di Aceh. Analisis ini memiliki urgensi yang penting berkaitan dengan basis data dalam kebijakan perwakafan di Provinsi Aceh. Oleh karena itu, penelitian ini diharapkan dapat menjadi desain awal dalam kebijakan perwakafan tanah di Provinsi Aceh.

\section{TINJAUAN PUSTAKA}

Definisi Imam Abu Hanifah memberikan pandangan bahwa sejatinya harta wakaf merupakan bentuk amalan kebajikan yang secara umum nilai kemanfaatannya bisa dirasakan oleh seluruh masyarakat/publik dengan kehendak dan persetujuan wakif. Hal ini dipertegas dalam definisi wakaf oleh Ulama Mazhab Syafi'i yang mengartikan wakaf adalah menahan harta yang bisa memberi manfaat serta kekal materi bendanya (al-'ain) dengan cara memutuskan hak pengelolaan yang dimiliki oleh wakif untuk diserahkan kepada nazir yang dibolehkan oleh syariah (asy-Syarbaini, 2000 dalam Tiswarni dan Hidayat, 2016).

Paradigma wakaf mengalami perkembangan dengan adanya perluasan makna dari menahan harta/benda berdasarkan aspek kemanfaatan. Pandangan yang menganggap asas kemanfaatan benda wakaf menjadi relevan sesuai dengan perkembangan zaman diargumentasikan berdasarkan praktik wakaf yang dilakukan oleh Umar bin Khaththab yang diikuti oleh Abu Thalhah yang mewakafkan kebun kesayangannya. Selanjutnya disusul oleh sahabat Nabi SAW lainnya, seperti Abu Bakar yang mewakafkan sebidang tanahnya di Makkah yang diperuntukkan kepada anak keturunannya yang datang ke Makkah. Utsman menyedekahkan hartanya di Khaibar. Ali bin Abi Thalib mewakafkan tanahnya yang subur. Mu'adz bin Jabal mewakafkan rumahnya yang populer dengan sebutan Dar alAnshar. Kemudian disusul oleh Anas bin Malik, Abdullah bin Umar, Zubair bin Awwam dan 'Aisyah Istri Rasulullah SAW (Kemenag, 2013).

Perkembangan praktik wakaf tanah sejatinya dilakukan dengan pertimbangan kebutuhan dan kelayakan ekonomi. Sejauh ini, data praktik wakaf masih banyak dilakukan untuk kepentingan pembangunan masjid (tempat peribadatan). Pemetaan potensi ekonomi sebelum pemberdayaan wakaf perlu dilakukan terlebih dahulu dengan mempertimbangkan aspek letak geografis tanah, seberapa besar dukungan masyaraat, peluang pasar, dan dukungan teknologi (Sutami, 2012).

Secara regulasi dalam perundang-undangan di Indonesia, wakaf diatur dalam UU No.41 Tahun 2004 yang mendefinisikan wakaf sebagai perbuatan hukum wakif untuk memisahkan dan/atau menyerahkan sebagian harta benda miliknya untuk dimanfaatkan selamanya atau untuk jangka waktu tertentu sesuai dengan kepentingannya guna keperluan ibadah dan/atau kesejahteraan umum menurut syariah. Perulasan makna wakaf dalam definisi ini menggambarkan bahwa konsep wakaf di Indonesia memberikan ruang adanya pengembangan harta wakaf secara fleksibel untuk kepentingan publik. 
Sebelum dikeluarkan PP No.28 Tahun 1977 tentang Perwakafan Tanah Milik, kepengurusan dan tata kelola tanah wakaf tidak teratur dan tidak tertib hingga dapat menyebabkan terjadinya penyelewengan. Pasal 29 Undang-Undang Dasar 1945 menyatakan bahwa negara menjamin kemerdekaan tiap-tiap penduduk untuk memeluk agamanya masing-masing dan untuk beribadah kepada Allah SWT yang termasuk ibadah maliyyah, yaitu ibadah berupa penyerahan harta (mal) baik infak, hibah, dan zakat yang dimiliki seseorang berdasarkan ketentuan yang telah disyariatkan.

Regulasi wakaf pada tahun 2014 ditetapkan dengan lahirnya UU No. 41 Tahun 2004 tentang Wakaf yang terdiri dari 71 Pasal. UU No. 41 Tahun 2004 ini mengatur tata kelola wakaf dan perluasan harta/benda wakaf dalam spektrum yang lebih luas pemanfaatanya. Legislasi perkembangan regulasi wakaf di Indonesia semakin menguat dengan terbitnya Peraturan Pemerintah RI No. 42 tahun 2006 sebagai pelaksana dalam perwakafan pada UU No. 41 Tahun 2004. Salah satu poin penting dalam dua regulasi ini adalah mengamanatkan pembentukan Badan Wakaf Indonesia (BWI). Tugas BWI tertera dalam UU No. 41 Tahun 2004 tentang Wakaf pasal 47 ayat (2), yaitu merupakan lembaga independen yang bertugas memajukan dan mengembangkan perwakafan nasional.

Berkaitan dengan wakaf tanah, Kencana (2015) mengkompilasikan tata aturan wakaf tanah secara menyeluruh dalam urutan: UU Nomor 5 Tahun 1960 tentang Peraturan Dasar Pokok-Pokok Agraria, Peraturan Pemerintah Nomor 2 Tahun 1977 tentang Perwakafan Tanah Milik, Peraturan Menteri Dalam Negeri Nomor 6 Tahun 1977 tentang Tata Cara Pendaftaran Tanah mengenai Perwakafan Tanah Milik, Peraturan Menteri Agama Nomor 1 Tahun 1978 tentang Peraturan Pelaksanaan Peraturan Pemerintah Nomor 28 Tahun 1977 tentang Perwakafan Tanah Milik, Peraturan Direktorat Jenderal Bimbingan Masyarakat Islam Nomor Keputusan: 19/75/78 tentang Petunjuk Pelaksanaan Perwakafan Tanah Milik, Instruksi Presiden Nomor 1 Tahun 1991 tentang Kompilasi Hukum Islam.

Wakaf tanah dalam dimensi pemanfatannya mengalami sejumlah terobosan dalam rangka pengembangan dan pembangunan ekonomi. Pada umumnya, penelitian tentang wakaf dilakukan dalam bentuk studi kasus dan implentatif pada pemanfaatan rumah ibadah, pendidikan/pesantren, pemakaman, dan kegiatan sosial-kemasyarakatan. Dalam konteks implementatif, wakaf tanah sudah ada dan dilakukan semenjak lahirnya komunitas-komunitas muslim di beberapa daerah di Indonesia. Lembaga wakaf muncul bersamaan dengan lahirnya masyarakat muslim sebagai sebuah komunitas keagamaan yang pada umumnya memerlukan fasilitas-fasilitas peribadatan dan pendidikan untuk menjamin kelangsungannya seperti masjid, musala, dan pesantren (Huda, 2013).

Pemahaman dan pemberdayaan harta wakaf di kalangan umat Islam berdasarkan hasil penelitian telah mengalami perubahan yang signifikan (Djunaedi dan Al Muin, 2015). Dari waktu ke waktu, pemahaman wakaf produktif semakin berkembang dan komprehensif yang bertujuan untuk mengembangkan ekonomi untuk kepentingan sosial masyarakat. Di Indonesia, masih banyak lahanlahan potensial yang belum difungsikan. Sekitar 30 juta hektar lahan potensial bisa digunakan untuk meningkatkan produktivitas pertanian dan perkebunan.

Probelematika tanah wakaf yang belum secara kompherensif dibahas pada banyak literatur adalah berkaitan dengan tabulasi data dan analisis statistik potensi wakaf di Indonesia. Kebutuhan akan basis data ini padahal mejadi menjadi basis utama dalam pengambilan kebijakan lokalisasi wakaf berdasarkan potensi yang ada.

Sekilas penelitian yang dilakukan oleh Susanto (2016) mengungkapkan data terbaru mengenai kondisi wakaf di Indonesia. Berdasarkan data Direktorat Wakaf Kemenag RI tahun 2016, dideskripsikan bahwa jumlah tanah wakaf di seluruh Indonesia adalah 435,768 lokasi tanah wakaf dengan luas keseluruhannya mencapai 4,359,443,170.00 $\mathrm{m}^{2}$. Namun demikian, sebagian tanah wakaf tersebut masih bermasalah karena baru $65.9 \%$ yang sudah berhasil tersertifikasi sedangkan yang lainnya yaitu sebesar $34.1 \%$ belum tersertifikasi. Artinya, masih cukup banyak tanah wakaf yang rawan terhadap berbagai masalah perdata maupun pidana. Tanah wakaf yang luas dan banyak tersebut seharusnya produktif dan memberi manfaat ekonomi yang signifikan bagi masyarakat Indonesia. 
Dampak wakaf terhadap pembangunan ekonomi yang mengambil case study of western therece oleh Sedar (2015) mengidentifikasi adanya komunitas wakaf yang digunakan dalam kegiatan administrasi untuk sektor real estate yang mencapai luasan lahan 655 ribu m², 149 kegiatan bisnis, sewa meyewa rumah, 8 masjid, dan 1 pusat kajian muslim. Lebih lanjut dijelaskan, keuntungan wakaf berkontribusi terhadap peningkatan pendapatan per kapita minoritas muslim di Uni Eropa.

Penelitian wakaf di Aceh dilakukan oleh Ibrahim, dkk (2016) yang menganalisis wakaf untuk sektor pendidikan. Dari hasil observasi penelitian, ditemukan bahwa tidak seluruh tanah wakaf telah dikelola dengan baik sehingga menghasilkan pendapatan yang maksimal. Tanah wakaf dalam bentuk kebun masih terbengkalai. Hanya terdapat beberapa jenis tanaman yang kurang berpotensi secara ekonomi. Masyarakat Aceh Besar dalam penelitian ini pada umumnya masih berpijak pada pemahaman fikih Imam Syafi'i yang tidak membolehkan pengalihan fungsi wakaf, termasuk untuk pendidikan sekalipun. Biasanya jalan keluar yang mereka tempuh di dalam pemenuhan keperluan pendidikan adalah dengan cara mewakafkan hartanya itu di awal untuk kepentingan pendidikan, sehingga dapat dimanfaatkan untuk kepentingan pendidikan.

Penelitian lain dalam konteks akuntabilitas pengelolaan wakaf di Baitul Mal Aceh dilakukan secara desktriptif oleh Maulida dan Ridwan (2017). Hasil penelitian ini menemukan bahwa akuntabilitas pengelolaan wakaf belum sesuai dengan UU No. 41 Tahun 2004. Baitul Mal Aceh tidak memiliki SOP pengelolaan wakaf dalam menyelenggaraan urusan karena Baitul Mal Aceh tidak mengelola wakaf. Beberapa catatan dalam penelitian ini mengungkapkan masih minimnya sosialisasi tentang Undang-Undang dan masih banyak ketimpangan yang terjadi dalam pengelolaan wakaf, sehingga banyak harta wakaf yang tidak tercatat dan dikelola dengan baik. Koordinasi BWI memang tidak mengatur pembentukan badan wakaf di Baitul Mal Aceh. Koordinasi hanya dilakukan pada pembentukan badan wakaf wilayah di Kanwil Kemenag Aceh pada sub bagian pengelolaan harta. Maka, dari sisi kelembagaan wakaf pada tingkat provinsi, perlu pendalaman lebih lanjut sehingga basis data yang digunakan dapat utuh dan merefleksikan pengelolaan wakaf yang sesuai dengan kebutuhan pembangunan daerah.

Provinsi Aceh pada dasarnya memiliki potensi yang optimal dalam pengembangan wakaf tanah. Siwak Kemenag RI (2018) menunjukkan bahwa Aceh berada pada urutan kedua setelah Sumatera Utara sebagai wilayah dengan cakupan tanah wakaf yang tinggi. Namun, konsentrasi wakaf tanah masih terpusat pada satu daerah yaitu Kab. Aceh Utara. Pada sisi yang lain, daerah dengan luasan wakaf yang tinggi seperti Kab. Aceh Utara dan Kab. Bireun belum optimal dalam pengurusan sertifikasi wakaf tanah.

\section{METODE}

Desain penelitian menggunakan analisis kualitatif dengan menelaah data wakaf tanah pada kabupaten/kota di Provinsi Aceh. Data utama bersumber dari Siwak Kemenag RI yang dikompilasikan pada tiap kabupaten/kota Provinsi Aceh. Untuk menginvetarisasi data wakaf tanah, maka tampilan data juga didukung dengan pemetaan wakaf tanah dengan metode Geospatial Information System (GIS) melalui Software Arcgis 10.3. Metode GIS diharapkan dapat memberikan rona tampilan yang lebih optimal dan memudahkan deskripsi lahan wakaf tanah yang potensial untuk dikembangkan. GIS dimulai pertama kali pada tahun 1960 yang bertujuan untuk melakukan analisis geografis wilayah. Kemampuan dasar dari GIS adalah mengintegrasikan berbagai operasi basis data seperti query, menganalisisnya serta menampilkannya dalam bentuk pemetaan berdasarkan letak geografisnya (Indraprahasta, 2013). GIS dalam telaah wakaf tanah di Provinsi Aceh akan menjadi database informasi spasial secara terpadu untuk perencanaan dan pengambilan keputusan.

Analisis deskripsi peta wakaf tanah Aceh melalui pemetaan akan didekati dalam tampilan overlay peta administrasi kabupaten/kota Provinsi Aceh. Peta administratif diperoleh dari Bappeda Provinsi Aceh. Hasil analisis akan memberikan gambaran dan alternatif pilihan lahan wakaf tanah yang 
potensial di Provinsi Aceh. Hasil pemetaan wakaf tanah yang terkumpul dan ditampilkan dalam peta wakaf tanah Provinsi Aceh akan menjadi landasan bagi desain kebijakan wakaf tanah.

Adapun objek penelitian ini terdiri dari dari tiga basis data yang terintegrasi :

1. Basis data wakaf tanah Provinsi Aceh pada tingkat kecamatan di seluruh kabupaten/kota

2. Basis data luas tanah wakaf yang telah tersertifikasi di seluruh kabupaten/kota

3. Basis data luas tanah wakaf yang belum tersertifikasi di kabupaten/kota Provinsi Aceh

Maka dalam identifikasi GIS yang dilakukan, hasil kompilasi data luasan tanah wakaf akan ditampilkan dalam bentuk peta wilayah wakaf tanah kabupaten/kota Provinsi Aceh. Sementara sertifikasi wakaf tanah dan penggunaan wakaf tanah dianalisis dengan mendeskripsikan distirbusi kepemilikan sertifikat pada lingkup kabupaten/kota Provinsi Aceh. Dalam studi ini, data sekunder penelitian menjadi komponen penting dalam telaah pemetaan yang dilakukan. Data sekunder ditinjau dari Sistem Informasi Wakaf (Siwak) Kemang RI, data Badan Wakaf Indonesia, dan data BPS distribusi penggunaan lahan. Pada bagian akhir, regionalisasi akan dideskripsikan dengan merumuskan kebijakan perwakafan di Provinsi Aceh dalam perspektif wakif dan nazir. Kedua pihak ini dianggap sebagai sasaran utama dalam pengembangan wakaf secara lebih luas dan berkelanjutan.

\section{PEMBAHASAN}

Wakaf sebagai sarana aktivitas muamalah bertujuan dalam rangka redistribusi harta/aset untuk kemaslahatan umat. Setidaknya, Ada dua hal pokok yang menjadi identifikasi pengukuran regionalisasi wakaf tanah di Aceh, yaitu wakaf tanah berdasarkan luasan lahan dan lokasi lahan wakaf. Berdasarkan data pada Siwak Kemenag RI (2018), total luas wakaf tanah Provinsi Aceh mencapai 760.55 ha dengan jumlah lokasi sebanyak 13,693. Berikut ini data wakaf yang berdasarkan luas lahan dan jumlah lokasi di Provinsi Aceh.

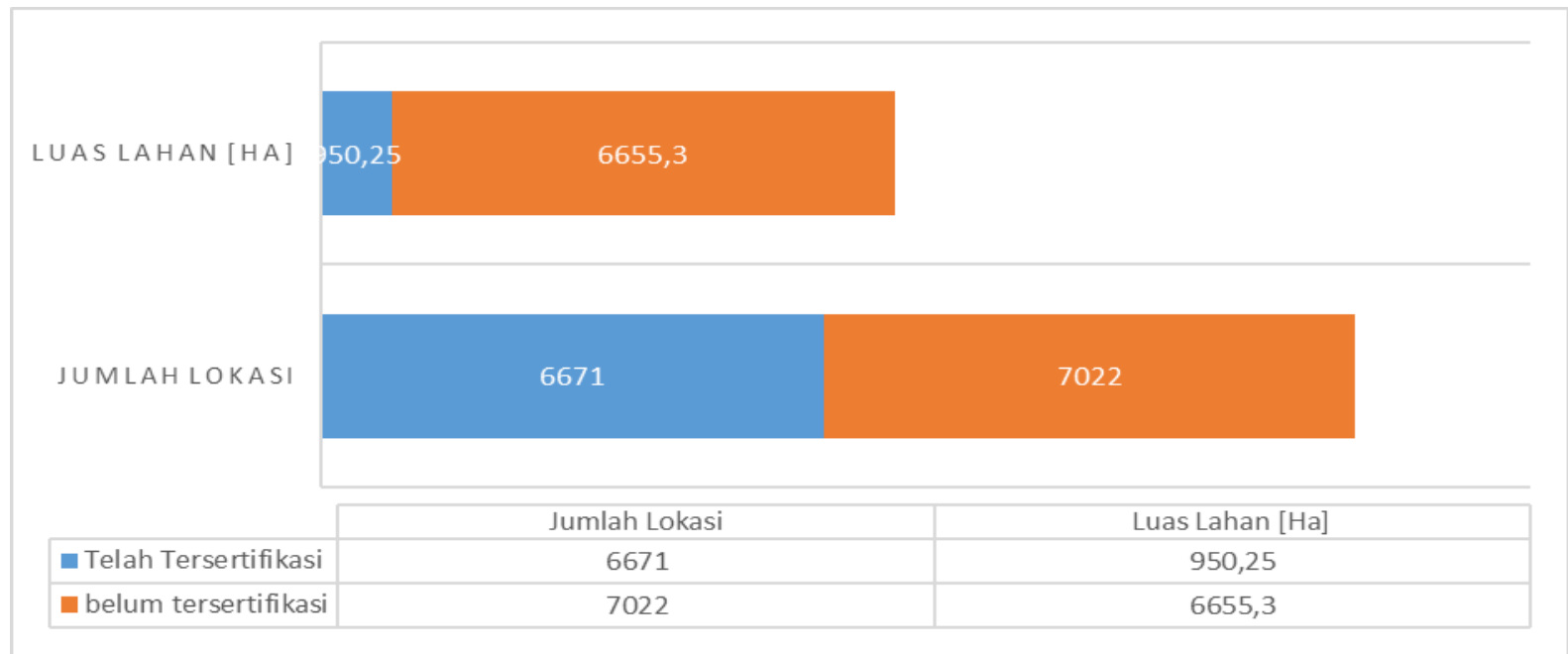

Sumber: Siwak Kemenag RI, 2018

Gambar 1 Data wakaf tanah berdasarkan luasan lahan dan jumlah lokasi di Provinsi Aceh

Berdasarkan hasil tabulasi data yang dilakukan, jumlah lahan yang telah tersertifikasi masih kecil porsinya. Dari total luas lahan wakaf di Aceh, hanya $12 \%$ yang memiliki sertifikat dan sisanya (88\%) belum memiliki sertifikat. Sementara itu, dari segi jumlah, titik lokasi wakaf yang yang telah tersertifikasi mencapai 49\%.Walaupun Aceh menduduki peringka kedua dalam jumlah luasan lahan wakaf tanah setelah Sumatera Utara, potensi wakaf tanah belum diiringi dengan proses sertifikasi wakaf tanah yang terdaftar di Badan Pertanahan Nasional (BPN). Proses penerbitan sertifikat tanah wakaf ini penting untuk memperkuat status legalitas tanah wakaf di kemudian hari. Apabila wakif 
mewakafkan tanah miliknya, maka perlu dilakukan ikrar wakaf sebagai pernyataan kehendak wakif yang diucapkan secara lisan dan/atau tulisan kepada nazir untuk mewakafkan harta benda miliknya dalam bentuk Akta Ikrar Wakaf (Fakhruddin, 2018). Pernyataan ikrar tersebut menjadi landasan penerbitan hukum yang tertuang dalam sertifikat wakaf tanah.

Jika ditelusuri dari segi penggunaan lahan, terlihat perkembangan wakaf tanah mengalami stagnasi dari tahun ke tahun. Penggunaan lahan di Provinsi Aceh masih didominasi oleh hutan yang sudah melebihi separuh dari total lahan yang digunakan. Wakaf tanah di Aceh terdistribusi sebesar 2\% pada tahun 2017. Data ini diperoleh dari penggunaan lahan Provinsi Aceh yang terbagi dalam beberapa penggunaan sebagai berikut :

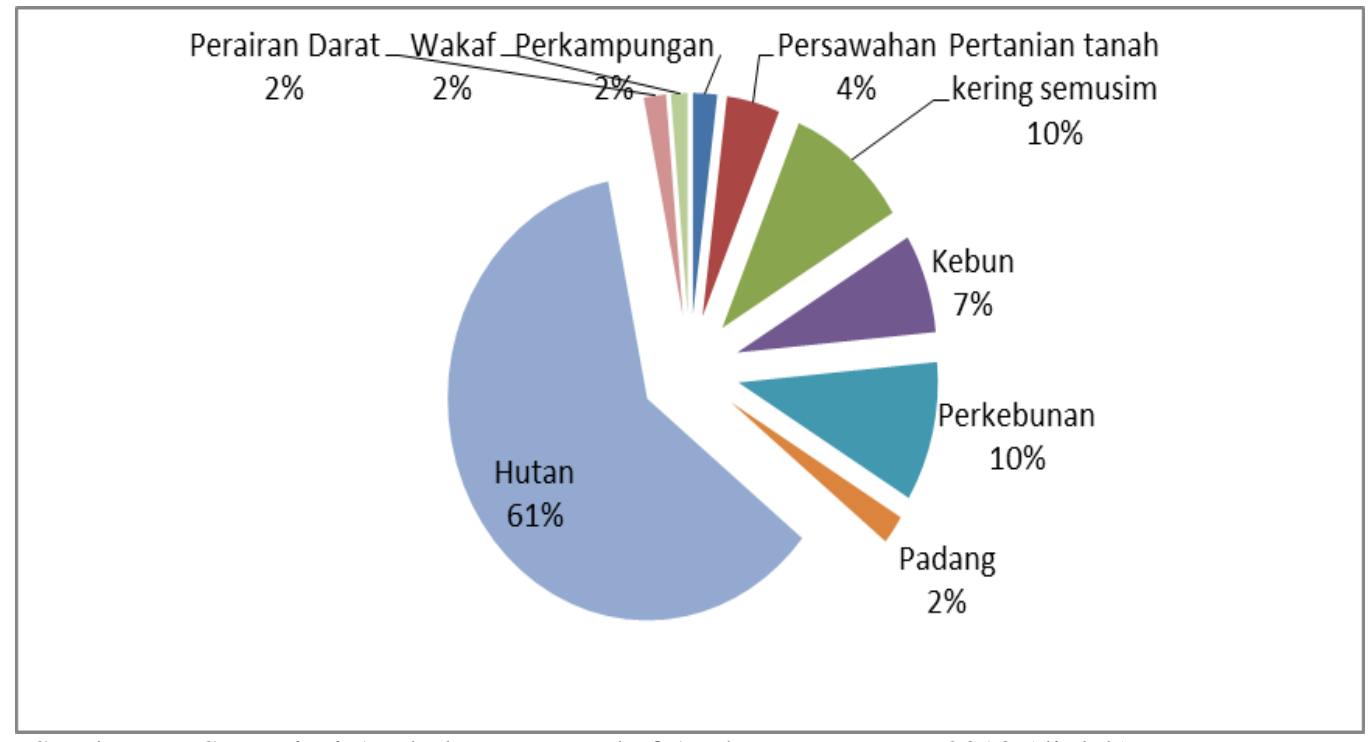

Sumber: BPS Provinsi Aceh dan Data Wakaf Aceh Kemenag RI, 2018 (diolah)

Gambar 2 Penggunaan lahan provinsi Aceh tahun 2017

Berdasarkan gambaran penggunaaan lahan Provinsi Aceh dengan total seluar 5.67 Juta Ha, distribusi persentase terserap dominan untuk penggunaan hutan sebesar 61\%. Jumlah ini menggambarkan bahwa lahan hutan yang dominan merupakan arah kebijakan forestry yang bersifat perlindungan. Jumlah penggunaan lahan yang besar juga banyak digunakan untuk perkebunan dan pertanian tanah kering semusim masing-masing $10 \%$.

Wakaf tanah Aceh yang terdata dari Sistem Informasi Wakaf Kemenag RI, masih sebesar 2 persen dari total penggunaan lahan. Kebijakan wakaf tanah perlu untuk dilakukan secara aglomeratif, yang menghimpun basis penggunaan wakaf berdasarkan potensi ekonomi. Sekilas dari data ini perlu dijabarkan lebih lanjut mengenai peta potensi wakaf tanah yang tersebar di 23 kabupaten/kota Provinsi Aceh.

\section{Potensi Wakaf Tanah Provinsi Aceh}

Potensi wakaf tanah di Aceh yang dihimpun dari Siwak Kemenag RI akan diidentifikasi pada dua hal utama, yaitu wakaf tanah secara luasan lahan yang sudah bersertifikat dan luasan lahan yang belum bersertifikat. Kedua data ini akan mampu menginventarisir daerah mana yang berpotensi untuk dikembangan wakaf tanah secara berkelanjutan. Berikut ini hasil pengolahan pemetaan GIS yang dieksplorasi berdasarkan peta administratif 23 kabupaten/kota Provinsi Aceh. 


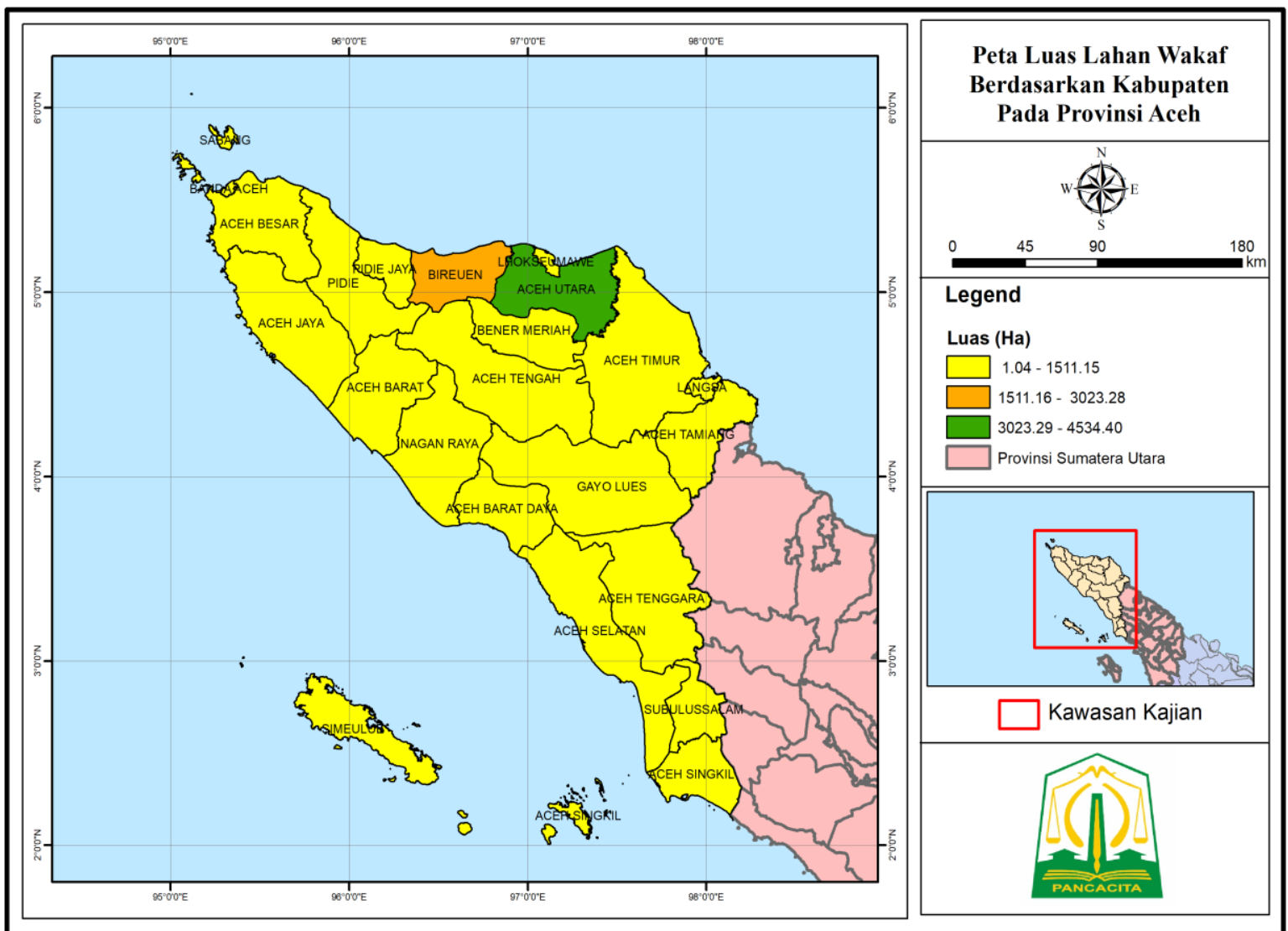

Sumber: Hasil Ouput Pemetaan GIS, 2018

Gambar 3 Peta luas lahan wakaf tanah kabupaten/kota Provinsi Aceh tahun 2018

Hasil pemetaan memunculkan dua isu utama berkaitan dengan potensi wakaf tanah Provinsi Aceh. Pertama, potensi wakaf belum secara merata terdistribusi pada kabupaten/kota. Secara rata-rata, wakaf tanah di Aceh berada dalam posisi luasan lahan sebesar 313 ha. Data menunjukkan bawah Kab. Aceh Utara paling dominan dalam kegiatan perwakafan tanah, yang mampu menyerap seluas 4534 ha atau 63\% dari total lahan wakaf di Aceh. Kedua, lahan wakaf tanah sebagian besar wilayah Provinsi Aceh hanya menyentuh $2 \%$ dari total lahan wakaf tanah secara keseluruhan. Dengan kata lain, jika Kab. Aceh Utara dihilangkan, maka lahan wakaf Aceh terdistribusi merata seluas 121 ha. Daerah yang teridentifikasi memiliki luasan tanah wakaf yang tinggi antara lain Kab. Bireun, Kab. Aceh Barat, dan Kab. Bener Meriah. Sementara itu, daerah yang luasan tanah wakafnya masih rendah berada di Kota Sabang, Kab. Simeulue, dan Kab. Aceh Tenggara.

\section{Sertifikasi Wakaf Tanah Kabupaten/Kota Provinsi Aceh}

Selain dari sisi luasan lahan, potensi wakaf tanah juga dapat dijelaskan berdasarkan sertifikasi wakaf tanah di Badan Pertanahan Nasional RI. Sertifikasi wakaf tanah penting dilakukan untuk kepastian kekuatan hukum pertanahan dalam pengelolaan wakaf. Tanah wakaf yang tidak tersertifikasi memiliki risiko mengalami gugatan kepemilikan tanah wakaf di kemudian hari sehingga nazir bisa kehilangan tanah wakaf. Dinamika kebijakan tata ruang dan wilayah di daerah juga mengakibatkan tanah wakaf yang belum tersertifikasi dapat beralih penggunaanya untuk kegiatan lain. Berdasarkan hasil tinjauan sertifikasi tanah wakaf di 23 kabupaten/kota Provinsi Aceh, luasan lahan wakaf yang tinggi di suatu daerah tidak diiringi dengan legalitas yang kuat dalam hal kepemiliki sertifikat tanah wakaf. Secara lengkap hasil tabulasi sertifikasi tanah wakaf di Provinsi Aceh digambarkan sebagai berikut: 


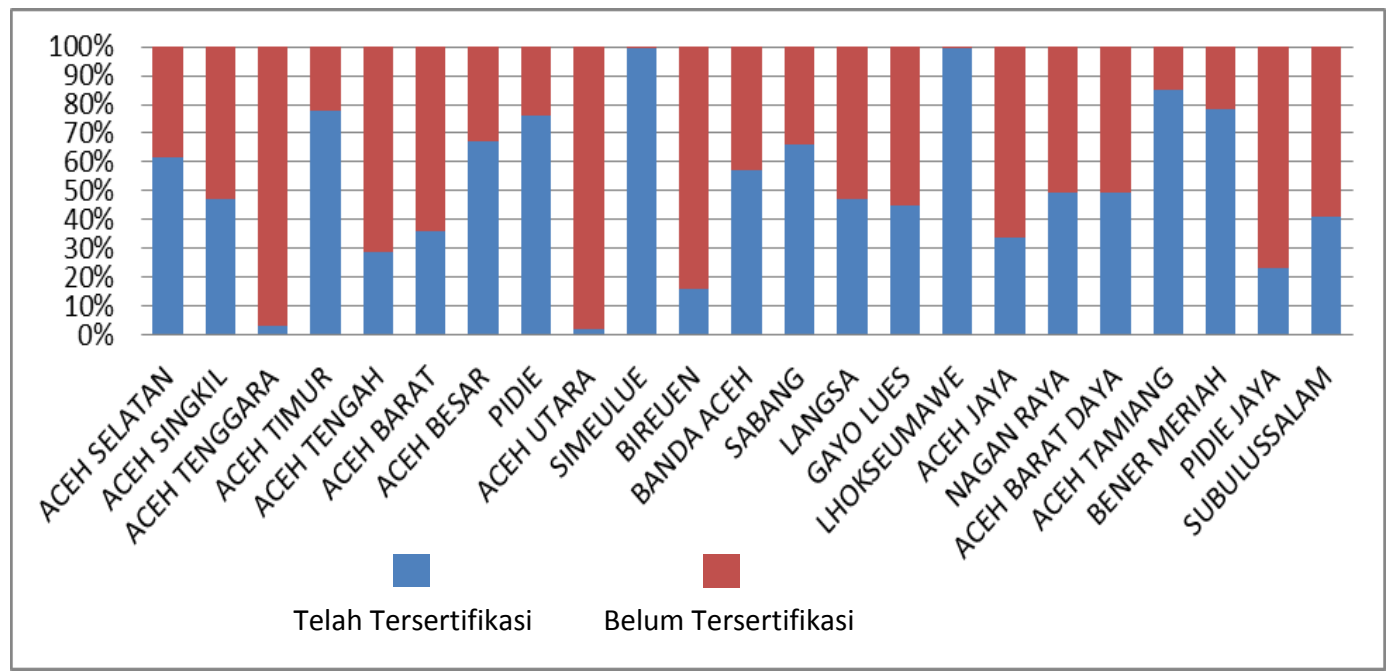

Sumber: Siwak Kemenag RI, 2018 (diolah)

Gambar 4 Perbandingan persentase luas wakaf tanah yang sudah dan belum tersertifikasi

Capaian tanah wakaf yang telah tersertifikasi pada 23 kabupaten/kota Provinsi Aceh memiliki ratarata persentase sebesar 51.76\%. Dari gambar di atas, dapat terlihat bahwa proses sebaran wakaf tanah yang tinggi di Provinsi Aceh belum diiringi dengan kepastian hukum dalam hal kepemilikan sertifikat wakat tanah. Daerah yang banyak memiliki sertifikasi wakaf tanah antara lain Kab. Simelulue, Kota Lhokseumawe, Kab. Aceh Tamiang, Kab. Bener Meriah, dan Kab. Aceh Timur. Sedangkan Kab. Aceh Utara, Kab. Aceh Tenggara, Kab. Bireun, Kab. Aceh Tengah, dan Kab. Pidir Jaya merupakan daerah yang belum banyak memiliki wakaf tanah yang tersertifikasi.

Kab. Simeulue yang hanya memiliki luasan wakaf tanah sebesar 11.2 ha, mampu melakukan sertifikasi wakaf tanah mencapai 99\%. Hal yang berbeda terjadi di Kab. Aceh Utara. Dengan luasan tanah wakaf yang tinggi sebesar 4534 ha, tanah yang tersertifikasi hanya seluas 100.64 ha atau sebesar $2.22 \%$.

\section{Potensi Wakaf Tanah Provinsi Aceh}

Potensi wakaf tanah di Provinsi Aceh memunculkan temuan adanya luasan tanah wakaf yang terkonsentrasi pada Kab. Aceh Utara sebesar 63\% dari total tanah wakaf. Namun demikian, proses sertifikasi ternyata belum sinkron dengan tanah wakaf pada daerah-daerah yang memiliki luasan yang tinggi. Maka, dilakukan kompilasi pemetaan wakaf tanah dari hasil simulasi GIS dan pendalaman pada data wakaf tanah yang telah tersertifikasi. Hasil kompilasi ini setidaknya mampu memberikan gambaran daerah-daerah mana saja yang teridentifikasi mampu dikembangkan sebagai wilayah perwakafan tanah. Potensi wakaf tanah dijelaskan dalam kuadran berikut ini : 


\begin{tabular}{|c|c|c|}
\hline Lanas & $\begin{array}{l}\text { Luasan Wakaf } \\
\text { Tanah di Atas Rata- } \\
\text { rata }\end{array}$ & $\begin{array}{l}\text { Luasan Wakaf Tanah di } \\
\text { Bawah Rata-rata }\end{array}$ \\
\hline $\begin{array}{l}\text { Persentase Luasan Wakaf Tanah } \\
\text { Bersertifikat di Atas Rata-rata }\end{array}$ & Tidak Ada & $\begin{array}{ll}\text { 1. } & \text { Aceh Selatan } \\
\text { 2. Aceh Timur } \\
\text { 3. Aceh Besar } \\
\text { 4. Pidie } \\
\text { 5. Simeulue } \\
\text { 6. Banda Aceh } \\
\text { 7. Sabang } \\
\text { 8. Lhokseumawe } \\
\text { 9. Aceh Tamiang } \\
\text { 10. } \text { Bener Meriah }\end{array}$ \\
\hline $\begin{array}{l}\text { Persentase Luasan Wakaf Tanah } \\
\text { Bersertifikat di Bawah Rata-rata }\end{array}$ & $\begin{array}{ll}\text { 1. } & \text { Aceh Utara } \\
\text { 2. } & \text { Bireun }\end{array}$ & $\begin{array}{l}\text { 1. Aceh Singkil } \\
\text { 2. Aceh Barat } \\
\text { 3. Aceh Tenggara } \\
\text { 4. Aceh Tengah } \\
\text { 5. Langsa } \\
\text { 6. Gayo Lues } \\
\text { 7. Aceh Jaya } \\
\text { 8. Nagan Raya } \\
\text { 9. Aceh Barat Daya } \\
\text { 10. Pidie Jaya } \\
\text { 11. Subulussalam }\end{array}$ \\
\hline
\end{tabular}

Sumber: Hasil Tabulasi Wakaf Tanah Provinsi Aceh, 2019 (diolah)

\section{Gambar 5 Kuadran potensi wakaf tanah di Provinsi Aceh}

Daerah dengan luasan tanah wakaf di atas rata-rata dan persentase tanah bersertifikat di bawah ratarata adalah Kab. Aceh Utara dan Kab. Bireuen. Kedua daerah ini dianggap memiliki potensi tanah wakaf yang luas, namun kesadaran nazir dalam mengurus sertifikat tanah masih rendah. Sementara itu, daerah dengan luasan tanah wakaf di bawah rata-rata dan persentase tanah bersertifikat di atas rata-rata antara lain Kab. Aceh Selatan, Kab. Aceh Timur, Kab. Aceh Besar, Kab. Pidie, Kab. Simeulue, Kota Banda Aceh, Kota Sabang, Kota Lhokseumawe, Kab. Aceh Tamiang, dan Kab. Bener Meriah. Kesepuluh daerah ini dianggap perlu meningkatkan pertumbuhan wakif tanah bagi pihakpihak yang memiliki distribusi luas lahan tinggi.

Potensi wakaf tanah di Provinsi Aceh menghasilkan temuan bahwa belum ada daerah di Provinsi Aceh yang memiliki luasan wakaf tanah di atas rata-rata dan persentase tanah bersertifikat di atas ratarata. Hal ini memperlihatkan bahwa kebijakan wakaf perlu dibangun secara sinergis dengan mempercepat proses pengesahan tanah wakaf yang tersebar di kabupaten/kota Provinsi Aceh. Lebih lanjut, intervensi pemerintah dalam pengembangan tanah wakaf perlu dilakukan dengan menerbitkan regulasi peraturan daerah yang mengatur wakaf tanah lebih berkelanjutan. Bentuk konkret peraturan daerah tentang pemberdayaan aset wakaf secara produktif dapat dilakukan dengan memberikan Rencana Tata Ruang Wilayah (RTRW) yang mengatur aspek tata kelola wakaf. 


\section{Kebijakan Wakaf Tanah Provinsi Aceh}

Hasil pemetaan dengan inventarisasi data Siwak Kemenag RI, menunjukkan perlu adanya ekosistem kebijakan strategis antar lembaga yang terpadu. Ekosistem kebijakan wakaf tanah sebagaimana dimaksud, terbagi dalam dua skema pendekatan kebijakan, yaitu perspektif wakif dan nazir. Alasan diperlukannya kebijakan berdasarkan dua skema tersebut adalah karena adanya daerah yang memiliki perbedaan potensi wakaf, sehingga pendekatan kebijakan perlu dilakukan pada dua persepektif.

Nazir wakaf adalah pihak yang mengelolaa objek wakaf (tanah) berdasarkan akad/perjanjian dengan pemilik tanah (wakif) untuk kemaslahatan mauquf 'alaih. Maka, nazir menjadi pihak yang perlu diperkuat dengan kelembagaan formil yang profesional. Pada bagian perspektif nazir, Kab. Aceh Utara dan Kab. Bireuen menjadi sasaran utama dalam kebijakan wakaf perspektif nazir. Kebijakan strategis yang dilakukan dalam hal ini tertuju pada nazir wakaf dengan tawaran skema sebagai berikut:

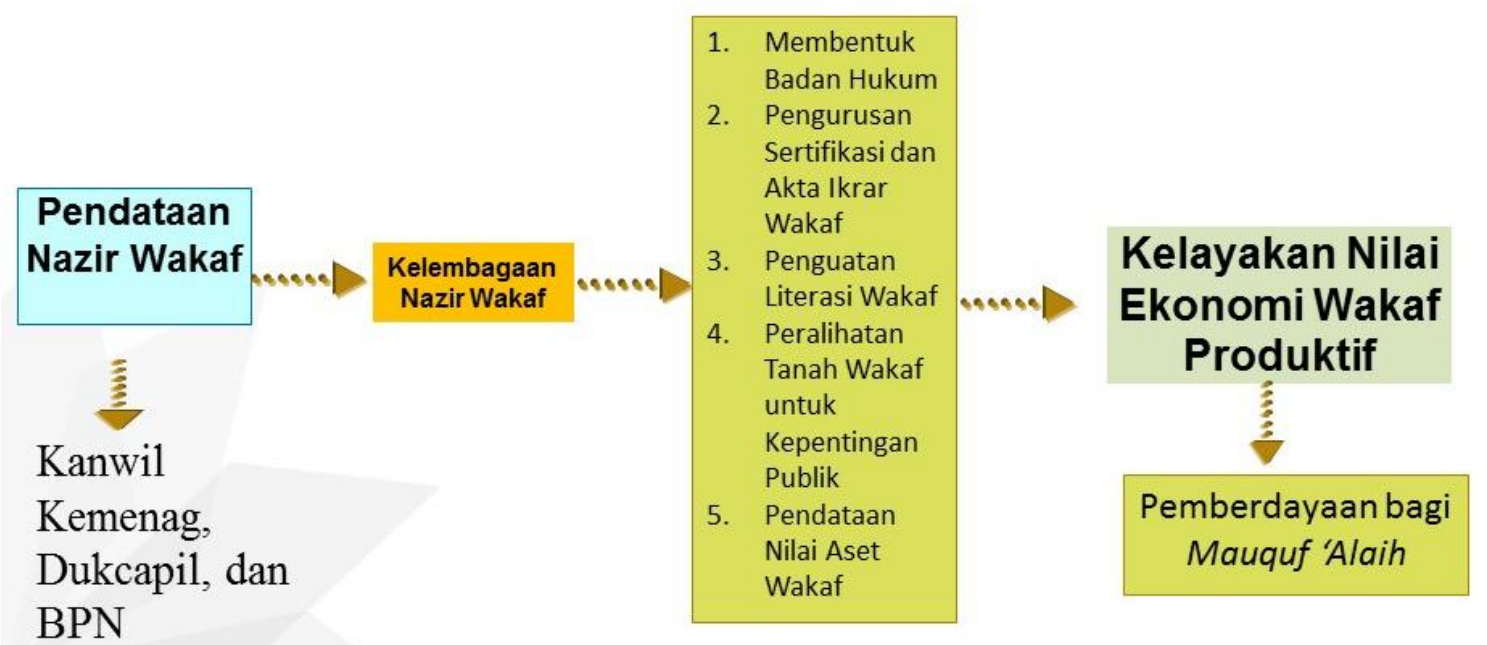

Sumber: Ilustrasi Penulis, 2019

Gambar 6 Skema kebijakan wakaf tanah perspektif nazir

Skema kebijakan wakaf tanah dapat dirumuskan dalam tahapan sebagai berikut :

1. Pemerintah dalam hal ini Kanwil Kemenag Aceh, Dukcapil Provinsi Aceh, dan BPN Wilayah Aceh melakukan pendataan yang optimal dengan langkah administrasi wakaf tanah beserta dengan para nazir.

2. Melakukan upaya integrasi nazir dengan membentuk kelembagaan nazir wakaf berdasarkan kelompok nazir pada aspek penggunaan wakaf untuk rumah ibadah, makam/kuburan, sosial pendidikan, dan ekonomi.

3. Nazir wakaf diberikan pengayaan pengelolaan wakaf dengan strategi :

a. Pembentukan badan hukum nazir wakaf untuk pengelolaan yang lebih profesional.

b. Pengurusan sertifikat tanah dan Akta Ikrar Wakaf untuk keberlanjutan pengelolaan wakaf yang clean and clear secara hukum.

c. Penguatan literasi wakaf bagi nazir dengan pelatihan dan bimbingan teknis pemanfaatan lahan wakaf.

d. Peralihan tanah wakaf produktif untuk kepentingan publik dengan menelusuri history tanah wakaf dengan catatan adanya akad yang memberikan kewenangan sepenuhnya pemanfaatan tanah kepada nazir.

e. Pendataan nilai aset wakaf untuk estimasi kemanfaatan di masa mendatang. 
4. Kebijakan penguatan nazir wakaf mempertimbangan kelayakan nilai ekonomis tanah yang produktif untuk digunakan sebesar-besarnya dalam rangka pemberdayaan mauquf'alaih.

Kebijakan berikutnya merupakan pendekatan perspektif wakif yang potensial untuk ditingkatkan pertumbuhan tanah wakafnya. Wakif sebagai pemilik tanah wakaf yang mendermakan harta/aset yang dimiliki menjadi unsur penting bagi perluasan lahan wakaf. Kebijakan strategis yang ditawarkan dapat digambarkan dalam skema berikut ini :

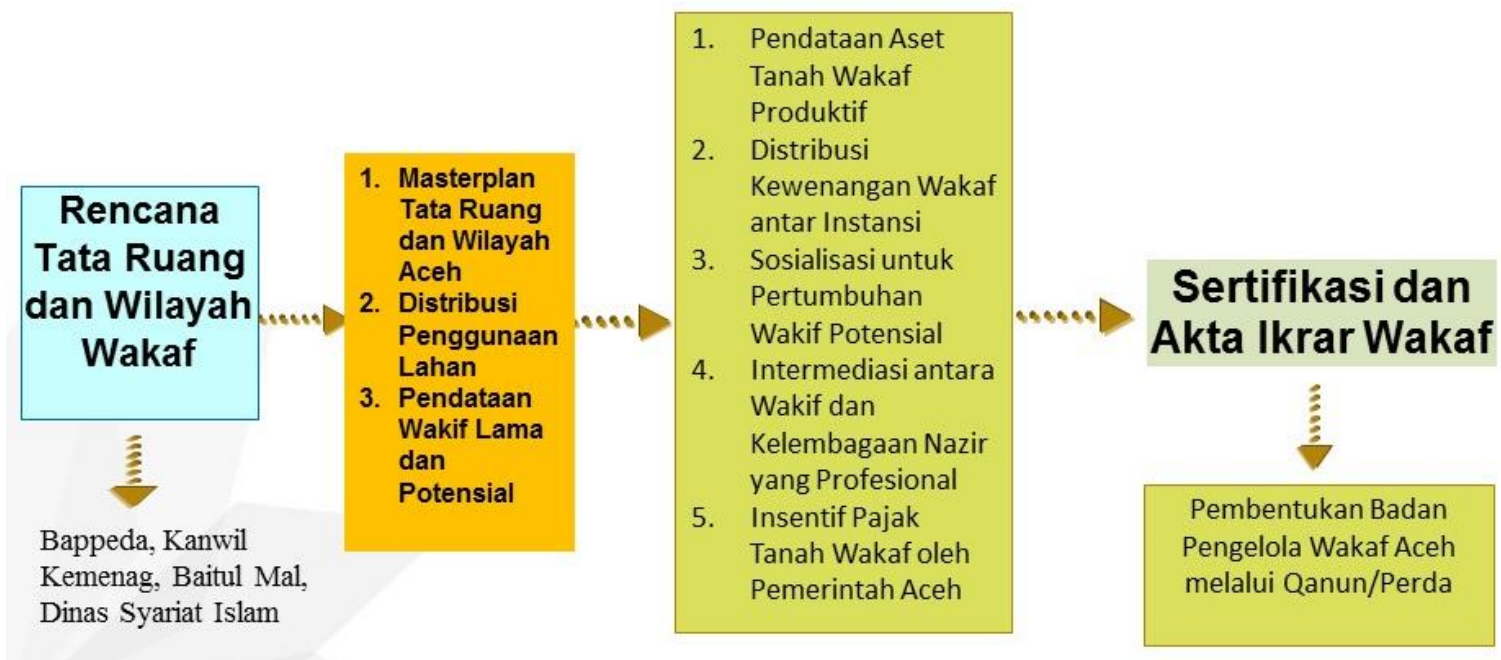

Sumber: Ilustrasi Penulis, 2019

Gambar 7 Skema kebijakan wakaf tanah perspektif wakif

Kebijakan wakaf tanah pada perspektif wakif tertuju pada daerah yang potensial memiliki luasan lahan bersertifikat di atas rata-rata. Jika diilustrasikan, maka skema kebijakan dapat dijelaskan sebagai berikut :

1. Membuat desain perencanaan tata ruang dan wilayah wakaf yang melibatkan komponen stakeholder unsur pemerintah seperti Bappeda Aceh, Kanwil Kemenag Aceh, Baitul Mal Aceh, dan Dinas Syariat Islam. Perencanaan ini perlu disusun dalam aksi kegiatan yang merepresentasikan visi Rencana Pembangunan Jangka Panjang (RPJP) Aceh 2012-2032. Visi pembangunan Aceh tahun 2005-2025 adalah kondisi Aceh diharapkan lebih islami, maju, damai, dan sejahtera sebagaimana tujuan nasional yang tertuang dalam Pembukaan Undang-Undang Dasar Negara Republik Indonesia Tahun 1945 (Qanun No. 12 tahun 2012).

2. Perencanaan tata ruang dan wilayah ini, setidaknya membahas subtansi masterplan tata ruang dan wilayah, alokasi distribusi penggunaan lahan, inventarisasi data wakif lama dan potensial. Penguatan ekosistem wakaf tanah penting dilakukan dengan memperkuat kebijakan sistem informasi wakaf tanah yang terintegrasi dengan Rencana Tata Ruang Wilayah (RTRW) Provinsi Aceh.

3. Aksi kebijakan yang ditawarkan dalam skema perspektif pertumbuhan wakif baru adalah :

a. Pendataan aset tanah wakaf produktif.

b. Distribusi kewenangan instansi wakaf.

c. Sosialisasi dengan pendekatan ceramah, khotbah jumat, dan pengajian majelis taklim mengenai materi wakaf tanah untuk pemberdayaan umat.

d. Kerjasama kelembagaan intermediasi untuk penguatan sistem pengelolaan wakaf produktif yang melibatkan Lembaga Keuangan Syariah.

e. Kebijakan insentif pemotongan pajak bagi para wakif untuk mendorong dan memperluas cakupan tanah wakaf. 
4. Skema kebijakan diharapkan dapat memperluas sertifikasi dan Akte Ikrar Wakaf baru yang nantinya dapat diatur dalam regulasi Perda/Qanun pembentukan badan pengelola wakaf Aceh untuk produktivitas tanah bagi mauquf 'alaih.

\section{SIMPULAN}

Regionalisasi wakaf tanah dengan upaya mendata wakaf tanah Provinsi Aceh yang didukung dengan sejumlah data dari Sistem Informasi Wakaf Kemenag RI, menyimpulkan beberapa hal pokok diantaranya:

1. Adanya konsentrasi luasan tanah wakaf yang besar pada Kab. Aceh Utara dan Kab. Bireuen. Namun demikian, daerah-daerah tersebut belum secara menyeluruh melakukan upaya sertifikasi wakaf tanah. Pada sisi lain, hasil inventarisasi data wakaf tanah menunjukkan 10 daerah yang memiliki kemampuan untuk mengadministrasi proses sertifikasi wakaf tanah. Daerah-daerah tersebut berpotensi untuk memperluas jangkauan wakaf tanah antara lain Kab. Aceh Selatan, Kab. Aceh Timur, Kab. Aceh Besar, Kab. Pidie, Kab. Simeulue, Kota Banda Aceh, Kota Sabang, Kota Lhokseumawe, Kab. Aceh Tamiang, dan Kab. Bener Meriah.

2. Adanya kelemahan dalam tata kelola wakaf dikhawatirkan dapat memperlemah legalitas wakaf tanah. Hasil kompilasi data luasan tanah dan sertifikat wakaf menghasilkan dua bentuk perumusan kebijakan wakaf tanah, yaitu kebijakan wakaf tanah perspektif nazir dan kebijakan wakaf tanah perspektif wakif.

3. Kebijakan wakaf tanah perspektif nazir memandang bahwa rangkain skema kebijakan perlu mengupayakan adanya pembentukan lembaga formal nazir wakaf yang profesional dalam pengelolaan lahan dengan mempertimbangkan aspek kelayakan nilai ekonomis wakaf di masa mendatang.

4. Kebijakan wakaf tanah perspektif wakif dengan pembentukan badan pengelola wakaf melalui regulasi setingkat Perda/Qanun di Aceh. Kebijakan ini perlu terintegrasi dengan instansi pemerintah daerah dalam basis perencanaan tata ruang dan wilayah Provinsi Aceh.

\section{ACKNOWLEDGEMENT}

Ucapan terimakasih kami ucapkan kepada Universitas Islam Negeri Ar-Raniry Banda Aceh sebagai pemberi dana bantuan penelitian yang bersumber dari DIPA UIN Ar-Raniry Banda Aceh Tahun Anggaran 2019 dalam Skema Penelitian Pembinaan/Peningkatan Kualitas Litapdimas Kemenag Republik Indonesia.

\section{DAFTAR PUSTAKA}

Abubakar, A. (2018, Maret 19). Baitul Asyi Wakaf Habib Bugak di Mekkah. Diambil dari: https://aceh.tribunnews.com/2018/03/19/baitul-asyi-wakaf-habib-bugak-di-mekkah.

Almizan, A. (2016). Pembangunan ekonomi dalam perspektif ekonomi Islam. Maqdis: Jurnal Kajian Ekonomi Islam, 1(2), 203-222.

Anas, A., \& Ryandono, M. N. H. (2017). Wakaf produktif dalam pemberantasan kemiskinan melalui pemberdayaan ekonomi di Yayasan Nurul Hayat Surabaya. Jurnal Ekonomi Syariah Teori dan Terapan, 4(3), 253.

Az-Zuhaili, W. (2011). Fiqih Islam Wa Adillatuhu terj. Abdul Hayyie al-Kattani, dkk. Jakarta (ID): Gema Insani.

[BPS] Badan Pusat Statistik Aceh. (2018). Aceh dalam Angka 2018. Aceh: BPS Provinsi Aceh.

[BWI] Badan Wakaf Indonesia. (2010). Pencanangan Gerakan Nasional Wakaf Uang oleh Presiden Republik Indonesia. Jakarta (ID), BWI.

Djunaedi, A. \& Al-Muin, N. (2015). Legalisasi status tanah bangunan masjid menjadi wakaf: Upaya memberikan perlindungan atas tanah-tanah wakaf. Al-Awqaf: Jurnal Wakaf dan Ekonomi, 8(1), 51-59. 
Fakhruddin, F. (2018). Pemetaan tanah wakaf di Kabupaten Karawang. Harmoni, 17(1), 152-171.

Huda, M. (2013). Mekanisme penciptaan tata kelola wakaf kreatif di Indonesia. Al-Awqaf: Jurnal Wakaf Dan Ekonomi Islam, 8(1), 94-107.

Huda, N., et al. (2015). Prioritas solusi permasalahan wakaf di Provinsi Jawa Barat dengan metode ANP. Al-Awqaf: Jurnal Wakaf dan Ekonomi, 8(1), 60-72.

Ibrahim, A. (2015). Prospek pemanfaatan tanah wakaf di Aceh: Suatu analisis untuk sektor pendidikan. Human Falah: Jurnal Ekonomi dan Bisnis Islam, 2(2), 38-58.

Indraprahasta, G. S. (2013). The potential of urban agriculture development in Jakarta. Procedia Environmental Sciences, 17, 11-19.

[Kemenag] Kementerian Agama. (2013). Paradigma Baru Wakaf di Indonesia. Jakarta (ID), Kemenag.

[Kemenag] Kementrian Agama. (2017). Kementerian Agama dalam Angka 2017. Jakarta (ID), Kemenag

Kencana, U. (2015). Konsep hukum pengelolaan dan pengembangan wakaf uang berbentuk saham dalam Perseroan Terbatas. Al-Awqaf: Jurnal Wakaf dan Ekonomi, 8(1), 1-16.

Maulida, R., \& Ridwan, R. (2017). Analisis akuntabilitas pengelolaan waqaf pada baitul mal provinsi aceh. Jurnal Ilmiah Mahasiswa Ekonomi Akuntansi, 2(4), 162-174.

Prihatini, F. (2005). Hukum Islam Zakat dan Wakaf. Jakarta: Kerjasama Penerbit Papas Sinar Mentari dengan Badan Penerbit Fakultas Hukum Universitas Indonesia.

Sedar, A. (2015). The Impact of Waqfs on Economic Development of the Ottoman Empire: The Case of Western Thrace, Research Gate.

[Siwak Kemenag] Sistem Informasi Wakaf Kementerian Agama. (2018). Grafik Jumlah Tanah Wakaf. Tersedia dalam pada http://siwak.kemenag.go.id/grafik_jumlah_tanah_wakaf.php. Diakses pada tanggal 09 Oktober 2019

Susanto, H. (2016). Eksistensi dan peran ekonomis harta wakaf. Hunafa: Jurnal Studia Islamika, 13(2), 316-342.

Sutami. (2012). Perkembangan wakaf di Indonesia. Al-Awqaf: Jurnal Wakaf dan Ekonomi, 5(2), 13 21.

Tiswarni, \& Hidayat, R. (2016). Kontribusi wakaf kapal nelayan untuk pemberdayaan ekonomi masyarakat. Al-Awqaf: Jurnal Wakaf dan Ekonomi, 9 (2), 96-117. 